\title{
Are Placental Cell-Derived Exosomes a Predictive Biomarker of Preeclampsia?
}

Alexander E Berezin*

Senior Consultant of Therapeutic Unit, Internal Medicine Department, State Medical University of Zaporozhye, 26, Mayakovsky av., Zaporozhye, Ukraine

\begin{abstract}
Placenta is endocrine organ that regulate biological function of several maternal tissues and fetal organs by specific mechanisms of cell-to-cell cooperation, which is realized via exosomes' secretion. Exosomes delivery some molecules, i.e., active proteins, pro-coagulants, growth factors, lipids, enzymes, micro-RNAs to target cells and induce autocrine / paracrine effects on vasculature and trophoblast. Interestingly, circulating number of exosomes derived from placenta cells in healthy pregnancies increases in $50-100$ fold times to healthy volunteers and they may be detected in several biological fluids across all gestation age starting with 6 weeks of gestation. Moreover, pregnancies at risk of preeclampsia exhibit extremely increased levels of total exosomes and placental cell-derived-exosomes in blood when compared with woman at risk free of preeclampsia. Taking into consideration this fact, measure of circulating number of placental cell-derived-exosomes could be an individual probe for personification of a risk of life-threatening event across pregnancy. The short communication is depicted the role of placental cell-derived-exosomes as biomarker of preeclampsia in asymptomatic pregnancies.
\end{abstract}

Keywords: Pregnancy; Preeclampsia; Exosomes; Vascular complications; Prediction, Biomarkers

Recent clinical studies have shown that placental cells may regulate biological function of maternal tissues and the majority of fetal organs across gestation through releasing of extracellular vesicles incorporated into secretom [1]. Indeed, circulating number of exosomes derived from placenta cells in healthy pregnancies increases in 50-100 fold times to healthy volunteers and they may be detected in several biological fluids across all gestation age starting with 6 weeks of gestation. Interestingly, asymptomatic pregnant woman at risk of preeclampsia may demonstrate extremely increased levels of total exosomes and placental cell-derived (CD63+)-exosomes (PCDE) in blood when compared with woman at risk free of preeclampsia $[2,3]$. In has been suggested that the risk of preeclampsia could associate with an altered relation between various phenotypes of PCDE. The circulating exosomes regulating fetal vascular response play a pivotal role in mobbing progenitor precursors, endothelial dysfunction, cell proliferation, inflammation, vasculogenesis and neoangiogenesis [4,5]. They are key factors contributing in endogenous vascular reparative processes and adaptation to hypoxia / ischemia-induced injury of cytotrophoblast [5]. Depending on their origin (activated or apoptotic fetal cells) exosomes appear to be distinguished in morphology, immune phenotypes, abilities to cargo some molecules (active proteins, pro-coagulants, growth factors, lipids, enzymes, micro-RNAs) and induce autocrine / paracrine effects on vasculature and trophoblast [6,7]. Apart from hypoxia /ischemia, insulin resistance, impaired fasting glucose, lipid toxicity and inflammation are recognized main regulators of cell secretom including exosomes [8]. On this occasion, a final effect of PCDE on target cells could be related to their structure, which is modified by several triggers.

It has been suggested that apoptosis of fetal cells may lead to secretion of exosomes that could directly worse endothelial function contributing in preeclampsia, while PCDE secreted by activated fetal cells may attenuate reparation and angiogenesis. Interestingly, there was no found increased activity of some anti-apoptotic factors, i.e., tissue matrix metalloproteinase inhibitor and survivin (a member of apoptosis proteins family inhibitors), which are actively transferred by exosomes, in physiological pregnancy. These anti-apoptotic molecules suppress caspases, influence on expression of vascular endothelial growth factor(s) and promote proliferative capability of endothelial cells and their precursors depending on gestation age [9], while their role in preeclampsia are still uncertain. Consequently, the results received recently [2] maintain the hypothesis that impaired immune phenotype of PCDE may be a personal biomarker of preeclampsia as life-threatening vascular complication in pregnancy.

\section{Conclusion}

In conclusion, large clinical trial requires explaining in details the role of various PCDE in predictive modality of clinical outcomes in pregnancies. The possibilities of individualized stratification in asymptomatic woman at risk of preeclampsia remain to be extremely intriguing.

\section{References}

1. Salomon C, Rice GE (2017) Role of Exosomes in Placental Homeostasis and Pregnancy Disorders. Prog Mol Biol Transl Sci 145: 163-179.

2. Salomon C, Guanzon D, Scholz-Romero K, Longo S, Correa P, et al. (2017) Placental exosomes as early biomarker of preeclampsia - Potential role of exosomal microRNAs across gestation. J Clin Endocrinol Metab.

3. Sarker S, Scholz-Romero K, Perez A, Illanes SE, Mitchell MD, et al. (2014) Placenta-derived exosomes continuously increase in maternal circulation over the first trimester of pregnancy. J Transl Med 12: 204.

4. Salomon C, Torres MJ, Kobayashi M, Scholz-Romero K, Sobrevia L, et al. A gestational profile of placental exosomes in maternal plasma and their effects on endothelial cell migration. PLoS ONE 9: 98667.

5. Atay S, Gercel-Taylor C, Kesimer M, Taylor DD (2011) Morphologic and proteomic characterization of exosomes released by cultured extravillous trophoblast cells. Exp Cell Res 317: 1192-1202.

*Corresponding author: Alexander E Berezin, Senior Consultant of Therapeutic Unit, Internal Medicine Department, State Medical University of Zaporozhye, 26, Mayakovsky av., Zaporozhye, Ukraine, Tel: +380612894585; E-mail: aeberezin@gmail.com (or) dr_berezin@mail.ru

Received June 09, 2017; Accepted June 13, 2017; Published June 15, 2017

Citation: Berezin AE (2017) Are Placental Cell-Derived Exosomes a Predictive Biomarker of Preeclampsia? Med Chem (Los Angeles) 7: 186-187. doi: 10.4172/2161-0444.1000454

Copyright: @ 2017 Berezin AE. This is an open-access article distributed under the terms of the Creative Commons Attribution License, which permits unrestricted use, distribution, and reproduction in any medium, provided the original author and source are credited. 
Citation: Berezin AE (2017) Are Placental Cell-Derived Exosomes a Predictive Biomarker of Preeclampsia? Med Chem (Los Angeles) 7: $186-187$. doi: 10.4172/2161-0444.1000454

6. Jung JJ, Tiwari A, Inamdar SM, Thomas CP, Goel A, et al. (2012) Secretion of soluble vascular endothelial growth factor receptor 1 (sVEGFR1/sFIt1) requires Arf1, Arf6, and Rab11 GTPases. PLoS ONE 7: e44572.

7. Wang S, Zaitoun IS, Johnson RP, Jamali N, Gurel Z, et al. (2017) Bim expression in endothelial cells and pericytes is essential for regression of the fetal ocular vasculature. PLoS ONE 12: e0178198.
8. Berezin AE, Kremzer AA, Samura TA, Berezina TA, Kruzliak P (2015) Impaired immune phenotype of circulating endothelial-derived microparticles in patients with metabolic syndrome and diabetes mellitus. J Endocrinol Invest 38: 865-874.

9. Karowicz-Bilińska A, Kowalska-Koprek U, Estemberg D, Sikora-Szubert A (2017) Evaluation of tissue metalloproteinase inhibitor TIMP-1 and Survivin levels during third trimester pregnancy - a preliminary report. Ginekol Pol 88 198-204. 